\author{
Helena Balcerek \\ ORCID: 0000-0003-2030-2797 \\ Uniwersytet Warszawski
}

https://doi.org/10.19195/1642-5782.19(29).5

\title{
Nauczanie (o) składni a kompetencja językowo-komunikacyjna uczniów z ASD
}

Rozważania dotyczące kształcenia językowego od lat oscylują wokół problemów różnicujących nauczanie o języku (teoretyczno-systemowe) i nauczanie języka (kompetencyjne). Już od lat dziewięćdziesiątych XX wieku sugerowana przez środowisko dydaktyków ${ }^{1}$ konieczność przemodelowania sposobu organizacji procesu kształcenia językowego, czyli zastąpienie modelu defunkcjonalnego, deskryptywno-paradygmatycznego, funkcjonalnym uczeniem o języku i języka, wydaje się w dalszym ciągu nie mieć pełnego zastosowania w praktyce szkolnej. Świadczą o tym ciągłe reformy programowe kształcenia i idące za nimi zmiany w programach, podręcznikach, modelach dydaktyki, wzorcach dobrych praktyk, standardach egzaminacyjnych ,wymuszające nieustanne przemyśliwanie na nowo zarówno podstaw teoretycznych kształcenia językowego, jak i praktycznych wdrożeń opracowanych czy tylko zmodernizowanych podejść i koncepcji”, jak pisze Jolanta Nocoń ${ }^{2}$.

Niniejszy artykuł ma charakter interdyscyplinarnych rozważań łączących problem funkcjonalnego kształcenia kompetencji językowo-komunikacyjnej (na-

${ }^{1}$ Opisywany już na początku lat dziewięćdziesiątych XX wieku w publikacjach metodycznych na przykład B. Niesporek-Szamburskiej, K. Orłowej, H. Synowiec, M. Nagajowej model funkcjonalnej nauki o języku opiera się na charakterystycznych rolach, jakie przypisuje się kształceniu językowemu głównie na drugim etapie edukacji, ponieważ na tym poziomie cele z obszaru kształcenia językowego realizowane są w największym stopniu i stanowią fundament do dalszej edukacji polonistycznej. Zob. B. Niesporek-Szamburska, K. Orłowa, H. Synowiec, O funkcjonalne nauczanie gramatyki ( $z$ badań nad procesem dydaktycznym w zakresie nauki o języku), „Z Teorii i Praktyki Dydaktycznej Języka Polskiego" 11, 1991; oraz M. Nagajowa, ABC metodyki języka polskiego, Warszawa 1995.

2 J. Nocoń, Lingwodydaktyka na progu XXI wieku. Konteksty — koncepcje - dylematy, Opole 2018, s. 38. 
uka o języku czy/i nauka języka) na poziomie szkoły podstawowej z problemem nauczania uczniów $\mathbf{z}$ diagnozą ASD (indywidualizacja i dostosowanie form oraz metod kształcenia). Celem jest zwrócenie uwagi na nauczanie gramatyki szkolnej na przykładzie składni, kojarzonej raczej z nauką o języku niż języka.

\section{Nauka języka czy/i nauka o języku we współczesnej szkole podstawowej}

W dzisiejszej lingwodydaktyce zajmującej się teorią i praktyką edukacji językowej ukształtowały się podejścia wspierające przemodelowanie organizacji procesu kształcenia językowego. Należą do nich między innymi³:

— podejście funkcjonalne przeciwstawione systemowo-normatywnemu;

— podejście komunikacyjne (obok funkcjonalizmu);

— podejście podmiotowe.

Zdaniem J. Nocoń podejście funkcjonalne nauki o języku dla nauki języka

zakłada zastąpienie w procesie edukacji szkolnej tradycyjnej, sformalizowanej gramatyki opisowej, która umożliwia wyłącznie przyswojenie przez ucznia abstrakcyjnej wiedzy o budowie systemu językowego i nie wspiera innych zadań kształcenia językowego, gramatyką sfunkcjonalizowaną, tj. taką wiedzą o języku, która zyskałaby wymiar narzędzia przydatnego do percypowania świata i twórczego w nim funkcjonowania ${ }^{4}$.

Spójna, całościowa koncepcja opisująca model funkcjonalnej nauki o języku (wspomaganej refleksją nad językiem) opisana przez Jadwigę Kowalikową i Helenę Synowiec zakłada:

1. funkcjonalność wewnątrzsystemową (poznawanie właściwości i możliwości języka jako tworzywa tekstu, funkcje w obrębie systemu);

2. funkcjonalność tekstową (funkcje w konkretnych użyciach);

3. funkcjonalność integracyjną (język jako klucz do interpretacji każdego tekstu — także literackiego);

4. funkcjonalność kreatywną (twórczy autorski wymiar wszystkich działań językowych);

5. funkcjonalność pragmatyczną (realizacja różnych form wypowiedzi);

6. funkcjonalność retoryczną (aspekt estetyczny i etyczny użycia języka w tekstach);

7. funkcjonalność kognitywną (język jako filtr poznawczy);

8. funkcjonalność komunikacyjną (swoisty nadwymiar obejmujący wszystkie pozostałe wymiary $)^{5}$.

${ }^{3}$ Za: ibidem, s. 49-117.

${ }^{4}$ Ibidem, s. 72.

${ }^{5}$ J. Kowalikowa, H. Synowiec, Miejsce nauki o języku w kształceniu językowym uczniów, [w:] Kształcenie sprawności językowej i komunikacyjnej. Obraz badań i działań dydaktycznych, red. Z. Uryga, M. Sienko, Kraków 2005, s. 49-54. 
Za szczególnie obiecujące dla edukacji językowo-komunikacyjnej w języku ojczystym uznaje się podejście zadaniowe, zgodne z koncepcją Europejskiego systemu opisu jakości kształcenia $(\mathrm{ESOJK})^{6}$. Lingwodydaktyczne podejście komunikacyjne przyjmuje, że ,uczenie języka polega na rozwijaniu językowych kompetencji komunikacyjnych, czyli kompetencji pozwalających uczestnikowi życia społecznego działać za pomocą środków językowych"” , na wykorzystaniu werbalnego lub/i niewerbalnego zachowania do osiągnięcia celów. Podstawowy model tak rozumianej kompetencji komunikacyjnej składa się z motywacji, wiedzy deklaratywnej i proceduralnej oraz umiejętności ${ }^{8}$. Niezwykle istotna dla lingwodydaktycznego podejścia komunikacyjnego okazała się również socjolingwistyczna koncepcja Stanisława Grabiasa, w której na sprawność (kompetencję) komunikacyjną składają się językowa sprawność systemowa, językowa sprawność społeczna, językowa sprawność sytuacyjna i językowa sprawność pragmatyczna ${ }^{9}$.

Zarówno podejście funkcjonalne, przeciwstawione systemowo-normatywnemu, jak i komunikacyjne koncentrują się na podmiotowym charakterze szkolnego kształcenia językowego, który stawia w pozycji nadrzędnej ucznia (podmiot, a nie przedmiot kształcenia wpisany w pozycji dominującej w modelu systemowo-normatywnym), jego możliwości poznawcze i potrzeby edukacyjne ${ }^{10}$. W dzisiejszej szkole podejście podmiotowe kształcenia (nie tylko językowego!) łączone jest (a przynajmniej powinno być) z promowaną i podkreślaną w dokumentach oświatowych indywidualizacją nauczania. Kordian Bakuła podkreśla: „W tym wszystkim ważny jest język, który służy ekspresji JA, porozumiewaniu się z TY, poznawaniu SIEBIE, JEGO, ŚWIATA"11. Spojrzenie na kształcenie językowe z perspektywy ucznia pozwala nauczycielowi dostrzec nie tylko sposób pojmowania języka przez uczącego się, poziom zrozumienia treści kształcenia, trudności i problemy, ale przede wszystkim dostosować formy i metody nauczania do jego indywidualnych możliwości i potrzeb. W konsekwencji doprowadzi do takiego określenia celów kształcenia, które będą realne do osiągnięcia i przełożą się na kompetencje językowo-komunikacyjne, pozwalające skutecznie porozumiewać się z innymi w różnych sytuacjach komunikacyjnych (nie tylko na lekcjach języka polskiego). Podmiotowe podejście wymaga sprofilowania procesu dydaktycznego na „człowieka żyjącego między ludźmi [...]; znaczenie wytwarzane i przekazywane przez język (bardziej wypowiedź niż system)"12.

\footnotetext{
${ }^{6}$ Zob. J. Nocoń, op. cit., s. 32.

${ }^{7}$ Cyt. za: ibidem, s. 58.

8 Zob. ibidem, s. 59.

${ }^{9}$ Zob. S. Grabias, Język w zachowaniach społecznych, Lublin 1997, s. 316-322.

${ }^{10}$ Zob. J. Nocoń, op. cit., s. 50-51.

${ }^{11}$ K. Bakuła, ,JA - NAJPIERW”. Ksztatcenie językowe wobec kulturowej teorii języka. Przewidywane zmiany miejsc, [w:] Podmiotowy wymiar szkolnej polonistyki, red. Z. Uryga, Kraków

12 Cyt. za: J. Nocoń, op. cit., s. 52.
} 1998, s. 155. 
W podstawie programowej z 2017 roku kształcenie językowe, rozumiane jako całokształt celów i treści kształcenia zorientowanych na wiedzę o języku/językową i sprawność językową/ kompetencjęjęzykowo-komunikacyjną na II etapie edukacji (wymagania ogólne) i treści nauczania (wymagania szczegółowe) przedmiotu język polski, zostało ujęte w dwóch obszarach, to jest - (II) kształcenia językowego, gdzie zasadniczą część stanowi gramatyka języka polskiego, i (III) tworzenia wypowiedzi obok kształcenia literackiego i kulturowego, i samokształcenia ${ }^{13}$. Można zatem wnioskować, że kształcenie językowe nie ma związku z kompetencją komunikacyjną - umiejętnością tworzenia wypowiedzi mówionych i pisanych. Wywołało to swoisty regres w dydaktyce polonistycznej i powrót dyskusji: nauka języka czy/i nauka o języku we współczesnej szkole podstawowej? Jolanta Nocoń ocenia taki zapis w podstawie programowej bardzo krytycznie:

Po raz pierwszy w historii dydaktyki przedmiotowej kształcenie językowe zostało oddzielone od tworzenia wypowiedzi — autorzy podstawy programowej z 2017 roku nie ujawnili jednak, jaka idea im przyświecała, gdy podejmowali tę decyzję [...]. Niejasnościom dotyczącym koncepcji wpisanej w podstawę programową towarzyszy brak konsekwencji, np. w wymaganiach ogólnych dla II obszaru zapisano konieczność kształcenia umiejętności mówienia i pisania, a dla obszaru III — rozwijanie umiejętności wypowiadania się. Oba sformułowania nie są rozłączne, a wręcz synonimiczne ${ }^{14}$.

\section{Podobnie wypowiada się Bernadeta Niesporek-Szamburska:}

Twórcy nowej Podstawy... werbalnie i hasłowo uznają zasady funkcjonalnego podejścia jako projektu całościowego, postulują wszak ,integralne traktowanie zagadnień języka i komunikacji, literatury i kultury". Pozostawienie jednak teorii w hasłowej deklaracji, nieobjaśnienie rozumienia funkcjonalności w przełożeniu na język dydaktyki, a przede wszystkim niewyrazistość koncepcji kształcenia języka, a właściwie — jej brak, świadczy o niezrozumieniu idei funkcjonalizmu oraz funkcjonalnego konstruowania z dziećmi (przez dzieci) wiedzy o języku. Nauczyciel polonista musi poradzić sobie z problemem braków w planie ramowym: to on dokonuje ostatecznej adaptacji dokumentu do konkretnych sytuacji lekcyjnych i pozalekcyjnych ${ }^{15}$.

Całościowy obraz sytuacji kształcenia językowego w przestrzeni szkolnej pogarsza jeszcze realizacja (i tak trudnych do zrozumienia) zapisów z podstawy programowej w praktyce lekcyjnej. Niestety wielu nauczycieli nie uwzględnia najnowszych koncepcji lingwodydaktycznych i realizuje model nauczania systemowo-normatywny, skupiając się tym samym na przekazaniu teoretycznej wiedzy o języku. Rozdysponowanie kształcenia językowego w podstawie programowej z 2017 na przeróżne punkty i podpunkty, w których dominuje gramatyka szkolna, przekłada się także na dominującą pozycję realizacji tych treści w praktyce szkolnej, nierzadko

${ }^{13}$ Zob. podstawa programowa kształcenia ogólnego dla szkół podstawowych, załącznik nr 2 do Rozporządzenia Ministra Edukacji Narodowej z dnia 24 lutego 2017 roku w sprawie podstawy programowej wychowania przedszkolnego oraz kształcenia ogólnego w poszczególnych typach szkół (Dz.U. z 2017 r. poz. 356).

14 J. Nocoń, op. cit., s. 40, przyp. 42-43.

15 B. Niesporek-Szamburska, Rozumienie ,funkcjonalnego podejścia do nauki o języku” w planie ramowym (podstawie) oraz w jego realizacji, „Annales Universitatis Paedagogicae Cracoviensis Studia ad Didacticam Litterarum Polonarum et Linguage Polonae Partinentia” 10, 2019, s. 237. 
całkowicie pozbawionej funkcjonalnego, podmiotowego podejścia. Pomimo że współczesne teorie lingwodydaktyczne oraz zapisy w dokumentach oświatowych ${ }^{16}$ obligują wszystkich nauczycieli do funkcjonalizmu, podmiotowości i indywidualnego podejścia $\mathrm{w}$ procesie nauczania, wielu z nich niestety nie uwzględnia ich w swojej codziennej pracy ${ }^{17}$.

\section{Specjalne potrzeby edukacyjne uczniów z ASD}

Dla współczesnej edukacji szkolnej niezwykle istotne znaczenie ma fakt, że kontekst lingwodydaktyczny, w jakim przebiega pierwotna socjalizacja językowa młodego pokolenia, ulega istotnym zmianom ${ }^{18}$. Wśród zmian społeczno-kulturowych zachodzi wyrównywanie szans edukacyjnych i uwzględnienie w procesie kształcenia specjalnych potrzeb edukacyjnych uczniów z dysfunkcjami i zaburzeniami rozwoju ${ }^{19}$. Powinno to wpływać na jeszcze głębszą interpretację trzech ukierunkowanych podmiotowo koncepcji lingwodydaktycznych. W takiej sytuacji funkcjonalność kształcenia językowego (szczególnie gramatyki „szkolnej”) powinna

${ }^{16}$ Mam tutaj na myśli przede wszystkim Rozporządzenie Ministra Edukacji Narodowej z dnia 24 lutego 2017 roku w sprawie podstawy programowej wychowania przedszkolnego oraz kształcenia ogólnego w poszczególnych typach szkół (Dz.U. z 2017 r. poz. 356); Rozporządzenie Ministra Edukacji Narodowej z dnia 9 sierpnia 2017 roku w sprawie zasad organizacji i udzielania pomocy psychologiczno-pedagogicznej w publicznych przedszkolach, szkołach i placówkach (Dz.U. poz. 1591).

${ }^{17}$ Opisane spostrzeżenia formułuję na podstawie obserwacji pedagogicznych i hospitacji lekcji prowadzonych w ramach czynnej pracy nauczyciela polonisty w warszawskich szkołach podstawowych od 2010 roku oraz dyskusji prowadzonych na konferencjach dydaktycznych od roku 2015, a także dydaktycznych publikacji naukowych.

18 Zob. J. Nocoń, op. cit., s. 11-48.

${ }^{19}$ Na podstawie ustawy z 1991 roku o systemie oświaty ówczesne Ministerstwo Edukacji Narodowej i Sportu wprowadzało od stycznia 2004 roku dodatkowe rozporządzenia w sprawie warunków organizowania kształcenia, wychowania i opieki dla niepełnosprawnych oraz niedostosowanych społecznie dzieci i młodzieży, polegające na wyrównywaniu ich szans edukacyjnych z edukacją dzieci rozwijających się prawidłowo. Założenia te ze zmianami funkcjonują do dziś. Zostały wpisane także w treść obowiązującej podstawy programowej z 2017 roku. Zob. preambuła Ustawy o systemie oświaty z dnia 7 września 1991 roku (Dz.U. z 2004 r. Nr 256, poz. 2572 z późn. zm.); Rozporządzenie Ministra Edukacji Narodowej z 17 listopada 2010 roku w sprawie warunków organizowania kształcenia, wychowania i opieki dla dzieci i młodzieży niepełnosprawnych oraz niedostosowanych społecznie w specjalnych przedszkolach, szkołach i oddziałach oraz ośrodkach (Dz.U. z 2014 r. poz. 392); Rozporządzenie Ministra Edukacji Narodowej z 17 listopada 2010 roku w sprawie warunków organizowania kształcenia, wychowania i opieki dla dzieci i młodzieży niepełnosprawnych oraz niedostosowanych społecznie w przedszkolach, szkołach i oddziałach ogólnodostępnych lub integracyjnych (Dz.U. z 2014 r. poz. 414); Rozporządzenie Ministra Edukacji Narodowej z dnia 20 lutego 2015 roku o zmianie ustawy o systemie oświaty oraz niektórych innych ustaw (Dz.U. poz. 357); podstawa programowa kształcenia ogólnego dla szkół podstawowych, załącznik nr 2 do Rozporządzenia Ministra Edukacji Narodowej z dnia 24 lutego 2017 roku w sprawie podstawy programowej wychowania przedszkolnego oraz kształcenia ogólnego w poszczególnych typach szkół (Dz.U. z 2017 r. poz. 356). 
być wiązana $\mathrm{z}$ umiejętnością przełożenia wiedzy gramatycznej na praktykę językową ucznia, czyli jego kompetencję kulturowo-komunikacyjną, w tym tekstotwórczą ${ }^{20}$. Niestety tak nie jest.

Podejście podmiotowe, funkcjonalne i komunikacyjne w kształceniu językowym szczególnie istotne jest w nauczaniu uczniów z zaburzeniami w spektrum autyzmu, których obecność w szkołach podstawowych stale wzrasta ${ }^{21}$. Pojęcie „zaburzeń w spektrum autyzmu" definiowane jest w najnowszym Diagnostic and Statistical Manual of Mental Disorders (DSM-5) z 2013 roku: Autism Spectrum Disorder (ASD) to spektrum zaburzeń w uniwersalnym rozmiarze, którego nie da się jednocześnie zdefiniować, ponieważ charakter występujących symptomów jest bardzo zróżnicowany i opiera się na dwóch kryteriach:

— stałych deficytach w zakresie komunikacji społecznej i społecznej interakcji;

- ograniczonych i powtarzających się wzorcach zachowania, zainteresowań lub aktywności ${ }^{22}$.

Kryteria diagnostyczne w DSM-5 łączą w sobie charakterystyczne trudności w ramach interakcji społecznych oraz komunikacji społecznej. Te pierwsze rozumiane są jako zachowania niewerbalne, a druga obejmuje zachowania zarówno werbalne, jak i niewerbalną umiejętność prowadzenia rozmowy (specyficzne zaburzenia syntaktyczno-semantyczne oraz zaburzenia semantyczno-pragmatyczne) ${ }^{23}$. Uczniowie $\mathrm{z}$ zaburzeniami w spektrum autyzmu są bardzo różnorodną grupą edukacyjną, zarówno pod względem funkcjonowania społecznego, komunikacyjnego, jak i intelektualnego. Niektóre dzieci autystyczne nie opanowują mowy i prezentują wyższy stopień niepełnosprawności intelektualnej oraz duże deficyty w rozwoju społecznym. Inne mogą być całkiem komunikatywne, czasami wręcz gadatliwe, nierzadko wykazują objawy przywiązania do osób znaczących (rodziców) przy jednoczesnych trudnościach w nawiązywaniu prawidłowych relacji z rówieśnikami oraz licznych schematyzmach w zachowaniu. Każdy przypadek ucznia z ASD może ujawniać inne zachowania i trudności, stąd w pedagogice powszechne jest behawioralne podejście do poznania i oceny ucznia z ASD 24 .

${ }^{20}$ Zob. A. Tabisz, Miejsce „szkolnej gramatyki” w kształceniu sprawności tekstotwórczych, [w:] Wiedza o języku i kompetencje językowe uczniów, red. B. Niesporek-Szamburska, Katowice 2012, s. 59.

${ }^{21}$ Wniosek na podstawie dokumentacji Mokotowskiego Wydziału Oświaty oraz własnych obserwacji prowadzonych $\mathrm{w}$ ramach pracy zawodowej nauczyciela języka polskiego w dwóch mokotowskich szkołach podstawowych w Warszawie w latach 2010-2019.

22 Zob. Diagnostic and Statistical Manual of Mental Disorders, Fifth Edition. DSM-5, Arlington 2013, s. 50: „Autism Spectrum Disorder, Diagnostic Criteria 299.00 (F84.0): A. Persistent deficits in social communication and social interaction across multiple contexts, as manifested by the following; B. Restricted, repetitive patterns of behavior, interests, or activities, as manifested by at least two of the following".

${ }^{23}$ Zob. T. Grandin, R. Panek, Mózg autystyczny. Podróż w głąb niezwyklych umysłów, przeł. K. Mazurek, Kraków 2017, s. 148.

${ }^{24}$ Zob. M.L. Sundberg, VB-MAPP. Ocena osiagania kamieni milowych rozwoju i planowanie terapii. Program do oceny umiejętności językowych i społecznych dzieci z autyzmem i innymi zaburzeniami rozwoju - PODRĘCZNIK, przeł. K. Chojnowska, M. Sierocka-Rogala, Warszawa 2015. 
W metodyce polonistycznej przez wiele lat termin zaburzeń autystycznych nie pojawiał się wcale. Fakt ten może dziwić ze względu na to, że w przeważającej liczbie przypadków osób z orzeczonym zaburzeniem tego typu podstawowym problemem jest komunikacja językowa. Zaburzona jest nie tylko sfera rozwoju języka, ale także, a może przede wszystkim, komunikacja społeczna, odbieranie, przetwarzanie, rozumienie i tworzenie tekstu lub wypowiedzi, co przecież stanowi nadrzędny cel edukacji polonistycznej. Kształcone w tym zakresie umiejętności są wykorzystywane w wielu sferach życia i funkcjonowania ucznia lub osoby dorosłej w społeczeństwie i kulturze.

Zaprezentowane $\mathrm{w}$ literaturze opisy badań ${ }^{25}$ implikują kilka symptomów zaburzenia, które należałoby uwzględnić w procesie kształcenia językowego uczniów z $\mathrm{ASD}^{26}$ :

1. Zaburzenia rozwoju mowy.

2. Utrudniony odbiór komunikatów werbalnych na poziomie przetwarzania dźwięków. Ze względu na zaburzenia integracji sensorycznej reakcja na dźwięki może być zbyt silna z towarzyszącym bólem lub widoczny będzie całkowity jej brak. Obserwuje się także obniżony poziom pamięci słuchowej i rozmywanie dźwięków mowy w zbyt długich komunikatach.

3. Problemy artykulacyjne. Najczęściej są wynikiem towarzyszącego zaburzeniom integracji sensorycznej słabemu lub silnemu napięciu mięśniowemu, czego skutkiem jest nieprawidłowa praca aparatu mowy.

4. Brak rozumienia, zapamiętywania, przyswajania odbieranych wypowiedzi, nazywane ślepotą znaczeniową ${ }^{27}$. Słyszane słowa nie mają żadnego znaczenia, mogą być bezwiednie powtarzane, ale z punktu widzenia semantycznego nie mają wymiaru komunikatu, nie posiadają żadnej treści. Dodatkowo utrudnione jest odczytywanie sygnałów społecznych i języka ciała (komunikatów pozawerbalnych), dlatego niezrozumiałe są metafory, komunikaty dotyczące kontekstów kulturowych lub niewyrażające treści bezpośrednio. Brak intencjonalności w odbieranych przez uczniów komunikatach, mgliste, bardzo ogólne znaczenie wypowiedzi, niewnoszące konkretnych dla ucznia treści, sugerują wniosek bezsensowności komunikowania się. A brak znaczeń wspólnych dla obu stron komunikacji językowej w konsekwencji ogranicza potrzebę kontaktów społecznych.

5. Trudności w stosowaniu w mowie czynnej różnego typu wypowiedzeń, budowaniu zdań pojedynczych i złożonych. Brak umiejętności tworzenia samodzielnych pełnych komunikatów, wypowiedzenia podane przez nauczyciela

25 Powołuję się na: T. Grandin, R. Panek, op. cit.; M. Mountstephen, Jak wykryć zaburzenia rozwojowe u dzieci i co dalej? Praktyczne rozwiąania do pracy z dziećmi w domu $i$ w szkole, przeł. J. Jedlińska, Warszawa 2011; M. Sundberg, op. cit.; E. Pisula, Autyzm u dzieci. Diagnostyka, klasyfikacja, etiologia, Warszawa 2001.

${ }^{26}$ Więcej na ten temat piszę w artykule: H. Balcerek, Wiedza o języku a problemy komunikacyjne uczniów z ASD, [w:] Kompetencje nauczyciela polonisty we wspótczesnej szkole. Między schematem a kreatywnościa, red. M. Trysińska, K. Maciejak, Warszawa 2019, s. 363-377.

27 T. Grandin, R. Panek, op. cit., s. 125. 
odtwarzane są biernie. Komunikacja polega na posługiwaniu się pojedynczymi wyrazami. W potrzebie nawiązania kontaktu pojawiają się ogromne frustracje wywołane nieskuteczną formą komunikowania się, brakiem zrozumienia przez odbiorcę oraz ograniczeniem narzędzi i umiejętności językowych niezbędnych do skutecznej komunikacji.

6. Specyficzne konstruowanie własnych wniosków i sądów. Charakterystyczne dla ASD wyobcowanie, zaburzenia rozwoju społecznego i emocjonalnego wywołują subiektywizację obserwacji i egocentryczne konstruowanie wniosków: „To, co ja myślę, jest jedyne i słuszne. To, co ty mówisz, jest nieprawdziwe”. Wypowiedź podparta jest subiektywnymi doświadczeniami, a to, co obce, jest odrzucane. Teorie niefunkcjonalne dla uczniów z ASD są ignorowane. Sztywne myślenie nie pozwala zrozumieć zachowań językowych w sytuacji niejednoznacznej, nie funkcjonują odniesienia kontekstowe. Poznawane pojęcia semantycznie i syntaktycznie rozumiane są przez pryzmat definicji słownikowych, ustalonych reguł i zasad językowych ujętych w opublikowanych dokumentach. Uczeń posługuje się opanowanymi wzorami - myślenie wzorcami ${ }^{28}$ — jeśli jakaś teoria, schemat są funkcjonalne dla niego, nie ma czego oceniać i sądzić.

7. Brak umiejętności tworzenia pytań i próśb. Zaburzenia przetwarzania informacji powodują, że wiedza dotycząca poznanego słowa - definicja systemowa, dźwięk, cechy gramatyczne - nie oznacza, że uczeń potrafi posługiwać się nim w celach komunikacyjnych. Podstawą są zdania oznajmujące, problem pojawia się w konstruowaniu spontanicznych funkcjonalnych pytań i próśb wywołujących określoną potrzebną reakcję odbiorcy - myślenie słowami, faktami ${ }^{29}$.

8. Problemy w redagowaniu wypowiedzi pisemnych, także w sferze sprawności graficzno-motorycznej.

Ze względu na zróżnicowanie symptomów oraz poziomu ich nasilenia, a także specyfiki zaburzenia u danego ucznia, w celu zniwelowania występujących problemów istotne jest realizowanie w praktyce szkolnej podejścia podmiotowego, funkcjonalnego i komunikacyjnego w kształceniu językowym, skupionego na „sprawnym komunikowaniu się w języku polskim”, a także dbałości „o wyposażenie uczniów w wiadomości i umiejętności umożliwiające komunikowanie się w języku polskim w sposób poprawny i zrozumiały"30.

\section{Nauczanie (o) składni}

Szczególne miejsce w szkolnym nauczaniu o języku, tradycyjnie ujmowanej gramatyce, rozumianej „po szkolnemu” jako całość wiedzy o języku w odniesieniu do systemu językowego, zajmuje składnia. Jerzy Podracki wyjaśnia, że:

\footnotetext{
28 Ibidem, s. 189.

29 Ibidem, s. 186.

${ }^{30}$ Podstawa programowa..., zał. nr 2, s. 12.
} 
Termin składnia bywa stosowany w dwóch różnych znaczeniach: 1) przedmiotowo - na oznaczenie odpowiedniego podsystemu języka (jest to funkcja wyrazu w zdaniu; układ zdania, jego budowa); 2) metajęzykowo - jako nazwa działu nauki o języku jest definiowana bardzo różnie zależnie od autora, przyjętej metodologii, stopnia szczegółowości określenia itp. [...]. Oto jeden z takich opisów definicyjnych:

„Dział gramatyki zajmujący się budową wypowiedzeń. Tradycyjnie do składni zaliczano badanie takich zjawisk, jak funkcje wyrazów w zdaniu (funkcja podmiotu, orzeczenia, dopełnienia i przydawki itd.), stosunki zależnościowe między wyrazami w zdaniu (składnia zgody, rządu, przynależności), szyk wyrazów. Składnię przeciwstawiano morfologii jako nauce o budowie wyrazów".

Składnia szkolna pozostaje w zasadzie w tym właśnie nurcie teoretycznym. Można ją nazywać szkolną, ponieważ taki model opisu syntaktycznego wykorzystywany jest w szkole podstawowej. Nazywana jest też składnią tradycyjną, gdyż metodologia ta oparta jest na dorobku europejskiej i polskiej myśli gramatycznej ${ }^{31}$.

Składnia to dział o tyle szczególny, że już od wielu lat uważana jest za najistotniejszą w dydaktyce języka, a sposób jej nauczania wielokrotnie poddawano krytyce $^{32}$. Wiedza na jej temat najczęściej zostaje wyłożona przez nauczyciela lub ,wyczytana” z podręcznika czy zeszytu ćwiczeń dedykowanego kształceniu językowemu i ma charakter wiedzy jawnej. Wiadomości te często nie są zintegrowane z innymi działami gramatyki. Dodatkowo autorzy nierzadko przedstawiają uczniom i nauczycielom podstawowe pojęcia językoznawcze w sposób niesystemowy, niespójny i nieuporządkowany ${ }^{33}$.

Kolejnym krokiem jest sprawdzenie, najczęściej w formie rozwiązywania gotowych ćwiczeń z tegoż samego podręcznika lub zeszytu ćwiczeń, w jakim stopniu uczeń nabył tę wiedzę. Ma ona charakter odtwórczy, zwerbalizowany, metajęzykowy, definicyjno-deskryptywny, terminologiczny. Dostępne na rynku wydawniczym przeanalizowane przez Justynę Pomierską zeszyty ćwiczeń o układzie:

najpierw teoria, w postaci zwięzłego zapisu wiedzy z gramatyki, prawideł w ramce, potem sprawdzenie, ile się z tego w ramce zapamiętało na podstawie kilku poleceń (wykropkowanych luk), krzyżówek, rebusów i innych zabaw językowych, szkodzą szkolnej nauce o języku. Nie mają związku z koncepcją komunikacyjną nauczania gramatyki, ani też z systemową wiedzą o języku, mimo że układ treści niezmiennie odwołuje się do czterech podstawowych działów gramatyki ${ }^{34}$.

Bardzo rzadko uwzględniają również dostosowanie formy i treści do specjalnych potrzeb edukacyjnych uczniów z ASD. J. Pomierska dodaje:

Drugie zło [zeszytu - H.B.] ćwiczeń to wielość, absorbowanie ucznia w takim stopniu, że nie ma już czasu na wykorzystanie zeszytu [przedmiotowego - H.B.]; [...]. Brakuje pracy nad notatką z lekcji nauki o języku, która zawierałaby jeden wyrazisty przykład czy wniosek będący efektem pracy

31 J. Podracki, Składnia, [w:] Nauka o języku dla polonistów, red. S. Dubisz, Warszawa 1994, s. $240-241$.

32 E. Awramiuk, O walorach ksztatcacych sktadni, [w:] Z problematyki kształcenia językowego, t. 2. Sktadnia - teoria a praktyka szkolna i akademicka, red. H. Sędziak, Białystok 2002, s. 230.

33 Zob. J. Podracki, K. Kozłowska, Części zdania w dydaktyce szkolnej. Czy i w jakim stopniu niezbędne?, [w:] Wiedza o języku..., s. 273.

34 J. Pomierska, Jak pomóc uczniowi w zrozumieniu pojęć z nauki o języku?, [w:] Wiedza o języku..., s. 93-94. 
badawczej ucznia, a wszystko zostałoby skomponowane samodzielnie lub przy pomocy nauczyciela na stronie formatu A5, w sposób pobudzający uwagę i pamięć uczącego się ${ }^{35}$.

Uczeń poznaje składnię na poziomie (para)naukowej abstrakcji i w oderwaniu od sytuacji użycia. W efekcie staje się znawcą gramatyki, zyskuje wiedzę między innymi o tym, z jakich jednostek i konstrukcji zbudowane są wypowiedzenia, potrafi te jednostki rozpoznać i opisać, zna reguły gramatyczne i wzorce paradygmatyczne ${ }^{36}$ oraz potrafi przedstawić to graficznie na wykresie. Niestety nie przekłada się to na funkcjonalne wykorzystanie wiedzy w budowaniu własnych wypowiedzi, nawet jeśli zgodnie z zapisami z podstawy programowej pojawią się pytania o to, jakie funkcje mogą pełnić poznane jednostki językowe w wypowiedziach, a środki językowe - w tekstach.

Bernadeta Niesporek-Szamburska pisze:

Analiza dokumentu ramowego wskazuje, iż w treściach Kształcenia językowego i Tworzenia wypowiedzi kilkanaście razy powtarzana jest też wiązana z funkcjonalnością funkcja w rozmaitych kontekstach, która ma być przez uczniów: „rozwijana”, „określana”, „,dostrzegana”, „rozumiana”, „rozpoznawana”, „wskazywana”. [...] autorzy Podstawy używają nazwy funkcji w zróżnicowanym znaczeniu: czasem jej rozumienie zdaje się sięgać do funkcji semantycznej, skierowanej ku materii tekstowej i rzeczywistości pozatekstowej (np. funkcje słownictwa w treściach części zatytułowanej Zróżnicowanie języka, funkcje wypowiedzeń klasyfikowanych semantycznie), jednak w treściach części 1. Kształcenia językowego, Gramatyki języka polskiego pojęcie funkcji sprowadza się najczęściej do dodatkowej wiedzy językowej — składniowej (np. do pełnienia roli członów zdania przez poszczególne części mowy). Czasem trudno też domyślić się, o który sens chodzi, gdy np. operacyjność celu przypisuje uczniowi opanowanie określania funkcji wyrazów poza zdaniem ${ }^{37}$.

Mimo że na potrzeby szkoły wiedza naukowa o składni zostaje znacznie okrojona i uproszczona, nie zmienia to faktu, że uczeń z ASD samodzielnie nie przełoży teorii na praktykę komunikacyjną. Bez pomocy nauczyciela, wskazówek świadczących o funkcjonalności naukowej wiedzy o składni, nawet najlepszy uczeń-znawca z ASD nie stanie się badaczem językoznawcą ${ }^{38}$. Trudno się nie zgodzić z sądem, że bezrefleksyjne opanowanie gramatyki nie wystarczy do sprawnego posługiwania się językiem i to nie tylko w edukacji uczniów z ASD ${ }^{39}$. Bierna znajomość systemu sprawdzana pytaniami i poleceniami typu: „Co to jest podmiot?”, „Co to jest orzeczenie?”, „Na jakie pytania odpowiada przydawka?”, „Co określają w zdaniu dopełnienia?”, „Wypisz imiesłowowe równoważniki zdań”, „Podaj rodzaje zdań złożonych współrzędnie i podrzędnie”, „Zaznacz na wykresie grupę podmiotu i grupę orzeczenia" itp., nie zniweluje trudności i problemów komunikacyjnych uczniów z ASD. Wytrącenie uruchamianych przez ćwiczenia czynności z kontekstu komunikacyjnego implikuje jedynie zaprezentowanie

35 Ibidem.

36 Zob. J. Nocoń, Strategie nabywania wiedzy o języku przez ucznia (na przykładzie zadań podręcznikowych), [w:] Wiedza o języku..., s. 32.

${ }^{37}$ B. Niesporek-Szamburska, op. cit., s. 231-232.

38 Por. J. Nocoń, Strategie..., s. 32.

39 Zob. J. Podracki, K. Kozłowska, op. cit., s. 272. 
posiadanej przez ucznia wiedzy teoretycznej o języku oraz zasobu słownictwa. Należy także pamiętać o tym, że aparat pojęciowy składni tradycyjnej wiąże się z innymi składnikami szkolnej wiedzy językoznawczej: fleksją, kulturą i poprawnością języka oraz z ćwiczeniami $\mathrm{w}$ mówieniu i pisaniu ${ }^{40} \mathrm{w}$ jak najmniej „usztucznionych" sytuacjach komunikacyjnych. Pomocne byłoby zapewne wskazanie przez nauczyciela pewnego schematu, wzoru na zasadzie algorytmu składniowego, sprawdzającego się w rzeczywistej sytuacji komunikacyjnej, funkcjonalnego dla ucznia myślącego wzorcami ${ }^{41}$.

Dostosowanie metod i form kształcenia językowego skupione na osiąganiu celów nie tylko edukacyjnych, ale i terapeutycznych wymaga od nauczycieli nowego, refleksyjnego funkcjonalnego nauczania składni służącego ,kształceniu umiejętności porozumiewania się (słuchania, czytania, mówienia i pisania) w różnych sytuacjach oficjalnych i nieoficjalnych, w tym także z osobami doświadczającymi trudności w komunikowaniu się" ${ }^{\text {42 }}$ oraz osobom/uczniom posiadającym zaburzenia w sferze komunikowania się (miedzy innymi z ASD). Lekcje (o) składni szkolnej nie mogą ograniczać się do kodowania przez uczniów treści systemowych, pojęć, terminów czy analizy gramatycznej wypowiedzeń i rysowania wykresów pozbawionych logicznego, funkcjonalnego uzasadnienia. Zaburzenia w spektrum autyzmu wymuszają zmiany dotychczasowego modelu kształcenia na rzecz nauczania składni jako narzędzia (algorytmu składniowego) do poprawnego systemowo i pragmatycznie tworzenia wypowiedzi przez uczniów z ASD. Czy nie lepiej, zamiast usilnie „wyuczać” uczniów z zaburzeniami sprawności graficzno-motorycznej rysowania wykresów wypowiedzeń, wykorzystać symptomy schematyczności i myślenia wzorcowego w analizie logicznej wypowiedzeń i opisie funkcji i zależności w komunikacji w naturalnych sytuacjach? A dzięki predyspozycjom logicznego myślenia i odtwarzania analogii stworzyć matematyczne schematy (wzory z wykorzystaniem pojęć teoretycznych) zdań składniowych jako ,algorytmu” budowania poprawnych komunikatów. Motywacją do uczenia się składni i rozwijania kompetencji językowo-komunikacyjnej powinno być przede wszystkim wymierne dla uczniów z ASD niwelowanie ich podstawowych (już opisanych) trudności i problemów w komunikacji werbalnej.

\section{Na zakończenie}

Współczesne lingwodydaktyczne podejścia o podmiotowym charakterze szkolnego kształcenia językowego, a także zapis w podstawie programowej z 2017 roku obligują nauczycieli do:

\footnotetext{
40 J. Podracki, op. cit., s. 241.

${ }^{41}$ Przykłady takich schematów/wzorów podaję w: H. Balcerek, op. cit., s. 374-375.

42 Podstawa programowa..., zał. nr 2, s. 59.
} 
Uczniom z niepełnosprawnościami, w tym uczniom z niepełnosprawnością intelektualną w stopniu lekkim, nauczanie dostosowuje się do ich możliwości psychofizycznych oraz tempa uczenia się. Wybór form indywidualizacji nauczania powinien wynikać z rozpoznania potencjału każdego ucznia. Jeśli nauczyciel pozwoli uczniowi na osiąganie sukcesów na miarę jego możliwości, wówczas ma on szansę na rozwój ogólny i edukacyjny. Zatem nauczyciel powinien tak dobierać zadania, aby, z jednej strony, nie przerastały one możliwości ucznia (uniemożliwiały osiągnięcie sukcesu), a z drugiej — nie powodowały obniżenia motywacji do radzenia sobie z wyzwaniami ${ }^{43}$.

Nowa rzeczywistość szkolna i nowe potrzeby uczniów wymagają nowego spojrzenia albo przynajmniej głębszej interpretacji proponowanych przez lingwodydaktyków rozwiązań. W dalszym ciągu tylko niewielu polonistów układa swoje programy czy też dostosowuje te obecne do potrzeb i możliwości uczniów z ASD. Spora większość korzysta z opracowań przypisanych do serii podręczników. A te mimo coraz nowszych wydań i atrakcyjniejszej formy (strony graficznej) nie proponują nowych koncepcji realizacji treści kształcenia językowego. Wielu nauczycieli od lat nie zmienia swoich metod nauczania gramatyki, choć inne cele stawia się dziś edukacji i zmienił się podmiot kształcenia. Tymczasem dzieci z ASD ze względu na całościowe jakościowe zaburzenia w komunikowaniu się uczą się języka trudniej i wolniej niż dzieci rozwijające się prawidłowo. Zaburzenie rozwoju polega na tym, że nie posiadają wrodzonej kompetencji językowej i predyspozycji do zachowań werbalnych. Tym bardziej potrzebują sfunkcjonalizowanej wiedzy językowej, która automatycznie znosi podział na komponent teoretyczny i komponent praktyczny w kształceniu językowym na poziomie szkoły podstawowej. Wydaje się, że wkład programowy nie jest właściwy — w podstawie, programach nauczania, podręcznikach, wreszcie praktyce szkolnej — skoro poziom sprawności językowej uczniów staje się przedmiotem troski coraz szerszego grona językoznawców, dydaktyków języka, specjalistów neuro- i psycholingwistyki, a także wielu nauczycieli ${ }^{44}$. $\mathrm{Z}$ analizy wymagań z obszaru kształcenia językowego w podstawie programowej szkoły podstawowej dokonanej przez J. Nocoń wynika, że:

uczeń powinien mieć wiedzę pojęciową i funkcjonalną o języku [...], umieć przeprowadzić analizę języka na różnych poziomach jego struktury oraz używać języka poprawnie w mowie i piśmie [...]. Na pierwszy plan powraca zatem gramatyczno-normatywne podejście do kształcenia językowego z elementami, przynajmniej na pierwszy rzut oka, podejścia funkcjonalnego. W podstawie programowej z $2017 \mathrm{r}$. podejście komunikacyjne zostało zepchnięte na plan dalszy i raczej śladowo jest obecne w zapisach tych wymagań szczegółowych, które odwołują się do celu, intencji, sytuacji komunikacyjnej ${ }^{45}$.

Należałoby poddać głębokiej refleksji obecne współcześnie w dyskursie szkolnym podejście gramatyczno-normatywne czy systemowo-normatywne, skoro wywołuje tyle krytycznych komentarzy i dyskusji wobec nauczania uczniów roz-

43 Ibidem, s. 13.

${ }^{44}$ Por. Wstęp, [w:] Wiedza o języku..., s. 9.

45 J. Nocoń, Znawca języka czy człowiek komunikujacy się? O strukturze kompetencji językowo-komunikacyjnej ucznia klas IV-VI szkoly podstawowej wpisanej w podstawe programowa z 2017 roku, „Annales Universitatis Paedagogicae Cracoviensis Studia ad Didacticam Litterarum Polonarum et Linguage Polonae Partinentia" 10, 2019, s. 252. 
wijających się prawidłowo. Jeżeli w owej refleksji uwzględni się podmiotowość i indywidualizację nauczania - specjalne potrzeby i możliwości edukacyjne uczniów z ASD - wyłania się konieczność przemodelowania sposobu organizacji procesu kształcenia językowego. Nowy model uwzględniałby podejście funkcjonalne nauki o języku dla nauki języka, podejście komunikacyjne ESOJK, socjolingwistyczną koncepcję S. Grabiasa, teorie neurodydaktyczne i psycholingwistyczne dotyczące zaburzeń w spektrum autyzmu, i wreszcie koncentrowałby się na podmiotowym charakterze szkolnego kształcenia językowego. Reprezentacja praktyczna takiego modelu zaczynałaby się od rozpoznania umiejętności werbalnych, niewerbalnych i społecznych oraz barier językowych ucznia z ASD, a wynikające z diagnozy dane służyłyby dostosowaniu treści, celów edukacyjnych i terapeutycznych, metod i form kształcenia oraz rozwijaniu kompetencji językowo-komunikacyjnej.

\section{Bibliografia}

Awramiuk E., O walorach ksztatcacych sktadni, [w:] Z problematyki kształcenia językowego, t. 2. Składnia - teoria a praktyka szkolna i akademicka, red. H. Sędziak, Białystok 2002.

Bakuła K., ,JA - NAJPIERW”. Kształcenie językowe wobec kulturowej teorii języka. Przewidywane zmiany miejsc, [w:] Podmiotowy wymiar szkolnej polonistyki, red. Z. Uryga, Kraków 1998.

Balcerek H., Wiedza o języku a problemy komunikacyjne uczniów z ASD, [w:] Kompetencje nauczyciela polonisty we wspótczesnej szkole. Między schematem a kreatywnością, red. M. Trysińska, K. Maciejak, Warszawa 2019.

Diagnostic and Statistical Manual of Mental Disorders, Fifth Edition. DSM-5, Arlington 2013.

Grabias S., Język w zachowaniach społecznych, Lublin 1997.

Grandin T., Panek R., Mózg autystyczny. Podróż w głąb niezwykłych umysłów, przeł. K. Mazurek, Kraków 2017.

Kowalikowa J., Synowiec H., Miejsce nauki o języku w kształceniu językowym uczniów, [w:] Ksztatcenie sprawności językowej i komunikacyjnej. Obraz badań $i$ działań dydaktycznych, red. Z. Uryga, M. Sienko, Kraków 2005.

Mountstephen M., Jak wykryć zaburzenia rozwojowe u dzieci i co dalej? Praktyczne rozwiąania do pracy z dziećmi w domu i w szkole, przeł. J. Jedlińska, Warszawa 2011.

Nagajowa M., ABC metodyki języka polskiego, Warszawa 1995.

Niesporek-Szamburska B., Rozumienie ,funkcjonalnego podejścia do nauki o języku” w planie ramowym (podstawie) oraz w jego realizacji, ,Annales Universitatis Paedagogicae Cracoviensis Studia ad Didacticam Litterarum Polonarum et Linguage Polonae Partinentia” 10, 2019.

Niesporek-Szamburska B., Orłowa K., Synowiec H., O funkcjonalne nauczanie gramatyki (z badań nad procesem dydaktycznym w zakresie nauki o języku), „Z Teorii i Praktyki Dydaktycznej Języka Polskiego" 11, 1991.

Nocoń J., Lingwodydaktyka na progu XXI wieku. Konteksty — koncepcje - dylematy, Opole 2018.

Nocoń J., Strategie nabywania wiedzy o języku przez ucznia (na przykładzie zadań podręcznikowych), [w:] Wiedza o języku i kompetencje językowe uczniów, red. B. Niesporek-Szamburska, Katowice 2012.

Nocoń J., Znawca języka czy człowiek komunikujący się? O strukturze kompetencji językowo-komunikacyjnej ucznia klas IV-VI szkoly podstawowej wpisanej w podstawe programowa z 2017 roku, ,Annales Universitatis Paedagogicae Cracoviensis Studia ad Didacticam Litterarum Polonarum et Linguage Polonae Partinentia" 10, 2019. 
Pisula E., Autyzm u dzieci. Diagnostyka, klasyfikacja, etiologia, Warszawa 2001.

Podstawa programowa kształcenia ogólnego dla szkół podstawowych, załącznik nr 2 do Rozporządzenia Ministra Edukacji Narodowej z dnia 24 lutego 2017 roku w sprawie podstawy programowej wychowania przedszkolnego oraz kształcenia ogólnego w poszczególnych typach szkół (Dz.U. z 2017 r. poz. 356).

Podracki J., Składnia, [w:] Nauka o języku dla polonistów, red. S. Dubisz, Warszawa 1994.

Podracki J., Kozłowska K., Części zdania w dydaktyce szkolnej. Czy i w jakim stopniu niezbędne?, [w:] Wiedza o języku i kompetencje językowe uczniów, red. B. Niesporek-Szamburska, Katowice 2012.

Pomierska J., Jak pomóc uczniowi w zrozumieniu pojęć z nauki o języku?, [w:] Wiedza o języku i kompetencje językowe uczniów, red. B. Niesporek-Szamburska, Katowice 2012.

Preambuła ustawy o systemie oświaty z dnia 7 września 1991 roku (Dz.U. z 2004 r. Nr 256, poz. 2572 z późn. zm.).

Rozporządzenie Ministra Edukacji Narodowej z dnia 9 sierpnia 2017 roku w sprawie zasad organizacji i udzielania pomocy psychologiczno-pedagogicznej w publicznych przedszkolach, szkołach i placówkach (Dz.U. poz. 1591).

Rozporządzenie Ministra Edukacji Narodowej z 17 listopada 2010 roku w sprawie warunków organizowania kształcenia, wychowania i opieki dla dzieci i młodzieży niepełnosprawnych oraz niedostosowanych społecznie w specjalnych przedszkolach, szkołach i oddziałach oraz ośrodkach (Dz.U. z 2014 r. poz. 392).

Rozporządzenie Ministra Edukacji Narodowej z 17 listopada 2010 roku w sprawie warunków organizowania kształcenia, wychowania i opieki dla dzieci i młodzieży niepełnosprawnych oraz niedostosowanych społecznie w przedszkolach, szkołach i oddziałach ogólnodostępnych lub integracyjnych (Dz.U. z 2014 r. poz. 414).

Rozporządzenie Ministra Edukacji Narodowej z dnia 20 lutego 2015 roku o zmianie ustawy o systemie oświaty oraz niektórych innych ustaw (Dz.U. poz. 357).

Sundberg M.L., VB-MAPP. Ocena osiagania kamieni milowych rozwoju i planowanie terapii. Program do oceny umiejętności językowych $i$ społecznych dzieci z autyzmem i innymi zaburzeniami rozwoju - Podręcznik, przeł. K. Chojnowska, M. Sierocka-Rogala, Warszawa 2015.

Tabisz A., Miejsce „,szkolnej gramatyki” w ksztatceniu sprawności tekstotwórczych, [w:] Wiedza o języku i kompetencje językowe uczniów, red. B. Niesporek-Szamburska, Katowice 2012. 